Finanse, Rynki Finansowe, Ubezpieczenia nr 3/2017 (87), cz. 1

\title{
Ocena efektywności pracy audytora wewnętrznego w oddziale operacyjnym banku komercyjnego
}

\author{
Piotr Oleksyk ${ }^{*}$
}

\begin{abstract}
Streszczenie: $\mathrm{Cel}$ - Celem artykułu jest wskazanie najważniejszych czynników wspomagających ocenę pracę audytora wewnętrznego w oddziale operacyjnym banku komercyjnego. Rozwiązania organizacyjne w bankach komercyjnych redukują pracę oddziału komercyjnego do punktu sprzedaży i dystrybucji usług bankowych i ubezpieczeniowych. Ograniczone możliwości decyzyjne kierownictwa oddziału banku są powodem powstawania zagrożeń operacyjnych, które na bieżąco mogą być eliminowane dzięki pracy audytora wewnętrznego. Ograniczone środki na funkcjonowanie audytu wewnętrznego nakazują, aby jego praca była jak najbardziej efektywna.

Metodologia badania - Badanie literatury jest punktem wyjścia rozważań. Badania te zostały uzupełnione o analizę problemów i zagrożeń najczęściej występujących w działalności banku. Wykorzystując wnioskowanie przez analogię oraz metodę dedukcyjną, wyznaczono najważniejsze obszary pracy audytora wewnętrznego w zakresie badania działalności oddziału operacyjnego banku komercyjnego.

Wynik - Przeprowadzone przez autora badania pozwalają na identyfikację kluczowych czynników oceny efektywności jego pracy w oddziale operacyjnym banku komercyjnego. Efektywna praca audytora ma na celu eliminację ryzyka działalności oddziału, jak również maksymalizację zysku wypracowywanego przez ten oddział przy spełnieniu wszystkich wymogów formalnych.

Oryginalność/wartość - Wartością artykułu jest autorska propozycja wieloaspektowej oceny efektywności pracy audytora wewnętrznego badającego działalność oddziału operacyjnego banku komercyjnego.
\end{abstract}

Słowa kluczowe: audyt wewnętrzny, bank, efektywność, ryzyko

\section{Wprowadzenie}

Nadzór nad ograniczaniem zagrożenia działalności banku ze względów organizacyjnych nie jest możliwy do realizacji tylko przez organy nadzorcze. Każdy bank ma obowiązek samodzielnie zatroszczyć się o własne bezpieczeństwo finansowe. Pierwszym z przejawów tej troski jest tworzenie wewnętrznych regulacji związanych z zarządzaniem ryzykiem. Ważne jest, aby rozwiązania te były zgodne z regulacjami zewnętrznymi i dodatkowo, aby były rozszerzeniem ram zawartych w regulacjach zewnętrznych. Samo tworzenie wewnętrznych regulacji jednak nie wystarcza. Bank musi zadbać o przestrzeganie wewnętrznych zasad przez wszystkie swoje jednostki organizacyjne, wśród których kluczową rolę spełnia

\footnotetext{
* dr Piotr Oleksyk, Uniwersytet Ekonomiczny we Wrocławiu, KTRiAF, Wydział Zarządzania, Informatyki i Finansów, e-mail: piotr.oleksyk@ue.wroc.pl.
} 
oddział operacyjny. Odpowiedzią na takie zapotrzebowanie jest tworzenie niezależnych komórek audytu wewnętrznego.

Audyt wewnętrzny jest niezależną, obiektywną działalnością oceniającą i doradczą, prowadzoną w celu wniesienia do organizacji wartości dodanej i doskonalenia jego działalności operacyjnej. Wspiera bank w osiągnięciu wytyczonych celów przez systematyczne i zdyscyplinowane podejście, którego celem jest ocena i poprawa efektywności zarządzania ryzykiem, systemów kontroli oraz zarządzania (por. Winiarska, 2010, s. 19). Bank narażony jest na różne rodzaje ryzyka, które mogą być ograniczane przez sprawnie działający audyt wewnętrzny - jego rola jest kluczowa i jak każdy rodzaj działalności powinna być jak najbardziej efektywna. Ze względu na to, że audyt wewnętrzny dysponuje dużym poziomem niezależności w zakresie opracowania rocznego planu swojej działalności, wszyscy badacze są zgodni, że efektywności audytu wewnętrznego nie powinno się ograniczać do wykonania planowanych lub nieplanowanych zadań zapewniających i czynności doradczych. Należy odnieść się do możliwie najbardziej obiektywnych kryteriów określania celów audytu wewnętrznego (Bednarek, 2015, s. 43).

Celem artykułu jest wskazanie najważniejszych czynników wspomagających ocenę efektywności pracy audytu wewnętrznego. Artykuł składa się z trzech części. W pierwszej zaprezentowano problem funkcjonowania audytu wewnętrznego $\mathrm{w}$ banku komercyjnym oraz problemy do rozwiązania, dotyczące jego zadań wobec oddziałów operacyjnych banku. W drugiej części omówiono najważniejsze metody oceny efektywności audytu wewnętrznego. W części trzeciej przedstawiono autorską propozycję procedury oceny efektywności pracy audytora wewnętrznego we wspomaganiu działalności operacyjnej oddziału banku. Wieloaspektowa ocena ma za zadanie wskazać efektywność pracy audytora, który powinien wspomagać sprawność działania oddziału oraz być jednym z ogniw eliminacji ryzyka bankowego.

\section{Specyfika audytu wewnętrznego $\mathrm{w}$ działalności banku komercyjnego}

System audytu wewnętrznego banku składa się z zasad, procedur, limitów, czynności i wszelkich mechanizmów stosowanych na wszystkich szczeblach działania banku w celu zapewnienia (por. Saunders, 1996, s. 26-32):

- rentowności operacji - poprzez efektywne wykorzystanie aktywów i innych zasobów (celem tych działań jest ocena zdolności do osiągania zamierzonych przychodów z jednoczesnym wykorzystaniem szans mających na celu zwiększenie efektywności prowadzonej działalności),

- ograniczania wszelakiego ryzyka działalności bankowej - w celu zabezpieczenia się przed stratą bank powinien w szczególności rozpoznawać, oceniać i kontrolować różne rodzaje ryzyka wynikające z prowadzonej działalności,

- przestrzegania przepisów prawa oraz regulacji wewnętrznych - ustanowiony system kontroli wewnętrznej powinien zapewnić, że cała instytucja bankowa przestrzega sto- 
sownych przepisów prawa, zasad bezpiecznego działania oraz wewnętrznych zasad polityki, procedur, regulaminów i przyjętej praktyki bankowej.

Rola audytora w procesie zarządzania ryzykiem operacyjnym jest kluczowa. Każdy bank indywidualnie dostosowuje strukturę organizacyjną departamentu audytu wewnętrznego. W większości banków komercyjnych audyt jest niezależną komórką centrali, która typuje oddziały operacyjne do przeprowadzenia badań audytowych. Postępująca cyfryzacja i centralizacja procesów wewnętrznych (Mikołajczyk, 2008, s. 211) doprowadza do sytuacji, w której oddziały operacyjne banków komercyjnych wykonują głównie czynności sprzedażowe. Jest to niestety przyczyna dodatkowego ryzyka organizacyjnego. Najważniejsze aspekty funkcjonowania audytu wewnętrznego w oddziale operacyjnym banku zaprezentowano na rysunku 1.

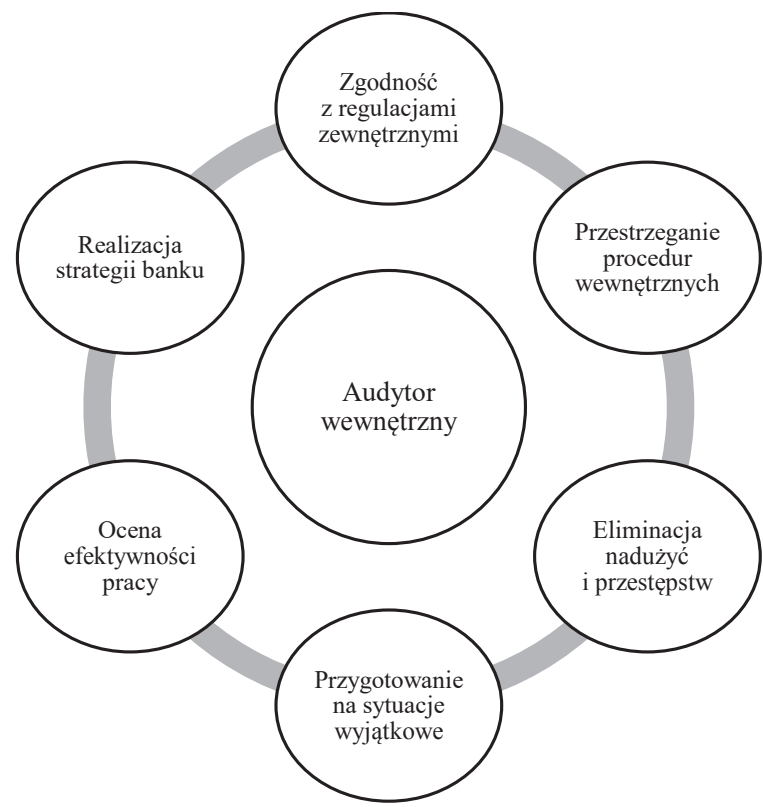

Rysunek 1. Rola audytu wewnętrznego w oddziale operacyjnym banku komercyjnego

Źródło: opracowanie własne.

Zaprezentowane na rysunku 1 obszary pracy audytora wewnętrznego w oddziale wskazują na przewagę działań związanych z ograniczaniem zagrożeń nad działaniami przyczyniającymi się do wzrostu efektywności działalności bankowej. W artykule podkreślono ważną rolę audytu wewnętrznego w zapewnieniu bezpieczeństwa finansowego banku. Wewnętrzne jednostki związane z kontrolą działalności całego banku są kluczowym ogniwem pozwalającym na oszacowanie wiarygodności przestrzegania zasad zarządzania i ograniczania ryzyka. Nadzór bankowy i inne instytucje zewnętrzne nie są w stanie na bieżąco 
weryfikować informacji zawartych w sprawozdawczości bankowej. Audytorzy wewnętrzni mogą na bieżąco kontrolować przestrzeganie zasad wynikających z systemu ograniczania ryzyka. Rozważania takie prowadzą do stwierdzenia, że audyt wewnętrzny jest niezbędnym i kluczowym wewnątrzbankowym ogniwem stojącym na straży bezpieczeństwa finansowego banku.

Nieprzewidziane i negatywne sytuacje zagrażające działalności oddziału banku mogą nastąpić w każdym momencie działalności. Strat ze zdarzeń operacyjnych - czyli sytuacji wynikających z codziennego stosowania procedur działania, które negatywnie wpływają na działalność oddziału - nie można uniknąć. Najważniejszym sposobem zabezpieczającym jest odpowiednie przygotowanie, pozwalające na szybkie działania zaradcze, które przyczynią się do minimalizacji ewentualnych strat.

Zdarzenia obarczone ryzykiem operacyjnym wymagają analizy wielu aspektów funkcjonowania oddziału operacyjnego banku, wśród których wymienić należy:

- niewłaściwe procedury związane z procesem obsługi klientów oddziału banku,

- niewłaściwie przeprowadzone rozliczenia pieniężne zarówno w obrocie kasowym, jak i elektronicznych systemach obsługi rachunków bankowych,

- wadliwie opracowane wzorce i umowy kredytowe, które mogą doprowadzić do braku możliwości skutecznej egzekucji należności kredytowych,

- oszustwa pracownicze oraz oszustwa podmiotów zewnętrznych jak również kradzieże oraz bezprawne wykorzystanie mienia oddziału,

- błędy powstałe wskutek niewłaściwie działających systemów informatycznych zarówno związanych z wewnętrznym osłabieniem zabezpieczeń systemu informatycznego banku, jak i negatywne skutki działań osób trzecich.

Nie należy jednak traktować pracy audytora wewnętrznego jako jedynego elementu zapewniającego bezpieczeństwo i efektywność pracy oddziału operacyjnego. Audytor nie może być zwykłym nadzorcą pracy oddziału komercyjnego. Efektywny audytor łączy w swojej pracy funkcję doradczą, zapewniającą oraz wspomagającą proces zarządzania. Konieczne jest więc badanie efektywności jego pracy.

\section{Pomiar efektywności audytu wewnętrznego}

Pomiar efektywności działalności jest ważny dla każdego podmiotu prowadzącego działalność operacyjną. Jednym z najważniejszych obszarów w audycie jest efektywność, która rzadko jest przedmiotem badań. Pomiar efektywności audytu wewnętrznego powinien być oparty na: określeniu celów, które mają zostać osiągnięte, wyznaczeniu mierników realizacji tych celów i ogólnej ocenie przydatności audytu wewnętrznego (Dittenhofer, 2001, s. 443). Działalność audytu wewnętrznego także powinna być na bieżąco badana i doskonalona (por. Zaleska, 2015, s. 98). W związku z tym w literaturze krajowej i zagranicznej coraz więcej uwagi poświęca się pomiarowi efektywności audytu wewnętrznego (Sawicka-Kluźniak, 2009, s. 433). Efektywność ta jest określana przez pryzmat zdolności komórki 
audytowej do wydawania ustaleń i formułowania zaleceń w ramach prowadzonych prac audytorskich. Miarą skuteczności audytu jest liczba wdrożonych zaleceń przez audytowane jednostki i komórki organizacyjne. $Z$ jednej strony efektywność audytu koncentruje się na zdolności audytora do planowania, realizacji zadań oraz zdolności do obiektywnego wydania zaleceń, z drugiej zaś jest składową czynników, które determinują funkcjonowanie komórki audytu (Bartoszewicz, 2015, s. 11).

Przeprowadzone badania literaturowe wykazują, że istnieją znaczące korzyści, jakie otrzymuje organizacja w wyniku efektywnego audytu wewnętrznego (Tomaszkiewicz, 2010, s. 119; Gos, 2013, s. 276). Pomiar efektywności audytu wewnętrznego jest procesem złożonym, uzależnionym od wielu aspektów wewnętrznych i zewnętrznych (Sojka, 2015, s. 121). Ważne jest, aby proces pomiaru efektywności audytora dostosować do potrzeb i specyfiki banku, w którym jest zatrudniony. Właściwie dobrane mierniki efektywności dadzą pełny obraz wyników pracy komórki audytu wewnętrznego w oddziale operacyjnym banku komercyjnego.

Pomiar efektywności pracy audytora wewnętrznego nieodzownie związany jest $\mathrm{z}$ analizą kosztów utrzymywania jego stanowiska w banku komercyjnym. Instytucje nadzoru bankowego nakazują jednak konieczność utrzymywania stanowiska audytora wewnętrznego jako kluczowego elementu eliminacji ryzyka. Obowiązek ten jest więc asumptem do wprowadzenia wieloaspektowej oceny efektywności funkcjonowania komórek audytu wewnętrznego. Wśród najważniejszych przesłanek świadczących o wysokiej przydatności komórek audytu wewnętrznego $\mathrm{w}$ aspekcie funkcjonowania oddziałów operacyjnych, należy wymienić:

- redukcję ryzyka bankowego,

- ograniczanie kosztów działalności,

- zapobieganie przestępstwom wewnętrznym,

- optymalizację procesów wewnętrznych,

- zwiększenie sprzedaży,

- efekt prewencyjny.

Pomiar efektywności pracy audytora wewnętrznego powinien być oparty na wskazanych czynnikach z uwzględnieniem specyfiki banku i wewnętrznej organizacji sieci sprzedaży poprzez oddziały operacyjne.

\section{Propozycja modelu oceny pracy audytora w oddziale operacyjnym banku komercyjnego}

Ocena efektywności audytu wewnętrznego w oddziale operacyjnym banku komercyjnego powinna być jednoznacznie powiązana ze zwiększeniem efektywności funkcjonowania tego oddziału. Oddziały operacyjne najczęściej oceniane są wieloaspektowo, co implikuje konieczność zastosowania analogicznych rozwiązań dla oceny pracy audytora. Nie może 
być to jednak symetryczny model oceny. Ocena efektywności oddziału operacyjnego oparta jest najczęściej na czterech kluczowych aspektach:

- zrealizowanych wynikach sprzedażowych,

- ponoszonych kosztach działalności,

- wzroście/spadku ryzyka działalności oddziału,

- liczbie błędów i przestępstw pracowniczych.

Nie należy jednak utożsamiać wprost wzrostu efektywności oddziału banku z efektywnością pracy audytora. Audytor może działać sprawnie i efektywnie, jednak jego zalecenia i rekomendacje mogą nie zostać wdrożone w działalności oddziału. Może również wystąpić odwrotna sytuacja. Poprawa efektywności i redukcja ryzyka działalności oddziału może nastąpić na skutek działań wewnętrznych, niepowiązanych z badaniem audytowym. Dobór mierników niezbędnych do oceny efektywności pracy audytora wewnętrznego powinien uwzględniać więc korelację osiąganych przez oddział wyników z tematyką i częstotliwością ostatnich badań audytowych przeprowadzanych w tym oddziale.

Mając na uwadze powyższe, w tabeli 1 zaprezentowano przykład wieloaspektowego modelu oceny efektywności pracy audytora wewnętrznego uwzględniającego specyfikę działalności oddziału operacyjnego banku komercyjnego.

\section{Tabela 1}

Obszary i mierniki oceny pracy audytora

\begin{tabular}{ll}
\hline Obszar oceny & Proponowane mierniki \\
\hline \multirow{2}{*}{ Redukcja ryzyka } & - przyrost/spadek liczby nieskutecznych egzekucji należności kredytowych, \\
& - przyrost/spadek liczby wadliwie przygotowanych umów z klientami, \\
& - przyrost/spadek liczby wadliwie zabezpieczonych kredytów \\
\hline & - liczba usprawnionych procedur redukujących czasochłonność obsługi klienta, \\
& pozwalających na obsługę większej liczby klientów, \\
Zwiększenie przychodów & - wartość zrealizowanych przychodów prowizyjnych i odsetkowych \\
& na podstawie działań wdrożonych po badaniu audytowym \\
\hline Ograniczenie kosztów & - liczba usprawnionych procesów redukujących zużycie materiałów i energii, \\
działalności & - liczba wdrożonych działań kontrolnych związanych z ponoszonymi kosztami, \\
\hline Eliminacja przestępstw & - wartość wykrytych i zredukowanych na podstawie zaleceń audytora strat \\
wewnętrznych & - przyrost/spadek przypadków wyłudzenia premii za wyniki sprzedażowe, \\
\hline
\end{tabular}

Źródło: opracowanie własne.

Analizując mierniki zaprezentowane w tabeli 1 należy zauważyć, że kompleksowo obejmują problemy działalności oddziałów operacyjnych banku komercyjnego i powinny być również stosowane w ocenie działalności audytora badającego ten oddział. Tak zdefiniowane obszary badania efektywności odzwierciedlają kompleksowość podejścia do współczesnego audytu wewnętrznego. Kompleksowość oceny efektywności pokrywa problem działań zapewniających oraz redukcję ryzyka. Nie wszystkie rodzaje ryzyka są możliwe 
do wyeliminowania przez audytora wewnętrznego. Przygotowanie banku do strat, których nie można uniknąć powinno być realizowane na poziomie centrali banku. Brak możliwości redukcji wszystkich rodzajów ryzyka nie powinien być odnoszony na pomiar efektywności audytu wewnętrznego na poziomie oddziału operacyjnego banku.

Przyszłe prace powinny koncentrować się na doskonaleniu modelu oceny pracy audytora przez ustalenie ważności obszarów badań. Konieczne jest ustalenie wag dla wskazanych obszarów badań audytowych. W opinii autora podstawą rangowania obszarów audytu powinny być wdrożone, na podstawie zaleceń audytorskich, działania które można oszacować w mierniku pieniężnym.

\section{Uwagi końcowe}

Przeprowadzone badania pozwalają na stwierdzenie, że pomiar efektywności pracy audytora wewnętrznego jest koniecznością, jednak jest to zadanie trudne do zrealizowania. Prawidłowo przeprowadzona ocena efektywności pracy audytora wewnętrznego w oddziale operacyjnym banku dostarcza korzyści, które mają różnorodny charakter. Wśród korzyści tych należy wymienić zwiększenie przychodów ze sprzedaży usług bankowych oraz redukcję kosztów funkcjonowania banku.

Pozostałe wnioski wynikające z przeprowadzonych badań są następujące:

1. Właściwie przeprowadzona ocena efektywności audytu wewnętrznego jest jednym z elementów redukcji ryzyka bankowego. Dzięki właściwie wyznaczonym obszarom oceny efektywności audytor skupia się w swoich badaniach na eliminacji negatywnych skutków zdarzeń, które są największym zagrożeniem dla banku.

2. Działalność audytu wewnętrznego w oddziałach operacyjnych banku komercyjnego jest znacząco odmienna od audytu w pozostałych komórkach organizacyjnych banku, dlatego wymaga odmiennych zasad oceny.

3. Funkcjonowanie komórek audytu wewnętrznego jest w działalności bankowej obowiązkowe. Zwiększenie efektywności ich funkcjonowania pozwala więc bankom na doskonalenie organizacji wewnętrznych kanałów sprzedaży z jednoczesnym eliminowaniem nieprzewidzianych uszczupleń wyniku finansowego.

\section{Literatura}

Bartoszewicz, A. (2015). Praktyczna realizacja programu zapewnienia i poprawy jakości w komórkach audytu wewnętrznego na wybranych przykładach. Zeszyty Teoretyczne Rachunkowości, 81 (137), 9-27.

Bednarek, P. (2015). Premie i nagrody dla audytorów wewnętrznych a skuteczność audytu wewnętrznego w sektorze prywatnym i publicznym. Prace Naukowe Uniwersytetu Ekonomicznego we Wroctawiu, 399, 41-54. DOI: 10.15611/pn.2015.399.04.

Dittenhofer, M. (2001). Internal auditing effectiveness: An expansion of present methods. Managerial Auditing Journal, $16(8), 443-450$.

Gos, W. (2013). Sprawozdawczość w zakresie audytu wewnętrznego i kontroli zarządczej. W: T. Kiziukiewicz (red.), Audyt wewnętrzny w strukturze kontroli zarządczej. Warszawa: Difin. 
Mikołajczyk, M. (2008). Bankowość detaliczna. W: M. Zaleska (red.), Współczesna bankowość. Warszawa: Difin.

Saunders, E.J. (1996). Kontrola wewnętrzna w oddziałach banków. Warszawa: Fundacja Rozwoju Rachunkowości w Polsce.

Sawicka-Kluźniak, Z. (2009). Efektywność audytu wewnętrznego. Zeszyty Naukowe Uniwersytetu Szczecińskiego. Finanse, Rynki Finansowe, Ubezpieczenia, 18, 431-439.

Sojka, K. (2015). Metody wewnętrznej oceny funkcjonowania audytu w jednostce sektora finansów publicznych. Zeszyty Naukowe Uniwersytetu Szczecińskiego, 864. Finanse, Rynki Finansowe, Ubezpieczenia, 76 (2), 121 131. DOI: $10.18276 /$ frfu.2015.76/2-10.

Tomaszkiewicz, A. (2010). Wartość dodana wnoszona przez audyt wewnętrzny. Acta Universitatis Lodziensis. Folia Oeconomica, 244, 111-112.

Winiarska, K. (red). (2010). Kontrola wewnętrzna w jednostkach gospodarczych. Warszawa: PWE.

Zaleska, B. (2015). Ocena funkcjonowania zleconego audytu wewnętrznego w wybranych jednostkach samorządu terytorialnego województwa zachodniopomorskiego. Zeszyty Naukowe Uniwersytetu Szczecińskiego, 864. Finanse, Rynki Finansowe, Ubezpieczenia, 76 (2), 89-98. DOI: 10.18276/frfu.2015.76/2-07.

\title{
EVALUATION OF THE EFFECTIVENESS OF THE INTERNAL AUDITOR IN THE COMMERCIAL BANK
}

\begin{abstract}
Purpose - The purpose of this article is to identify the most important factors supporting the assessment of the work of the internal auditor in the commercial bank's operating branch. Organizational solutions in commercial banks reduce the work of a commercial branch to the point of sale and distribution of banking and insurance services. The limited decision-making capabilities of the bank's branch management are the cause of operational risks that can be reduced by internal auditor. Limited resources for the internal audit function require that its work be as effective as possible.

Design/methodology/approach - Literature review is the starting point of the considerations of this article. These studies were supplemented by an analysis of the most common problems and threats in the bank's operations. Using inference through analogy and using a deductible method, the most important areas of work of the internal auditor in the area of the audit of the operational branch of a commercial bank were determined. Findings - Conducted by the author studies allow identification of the key factors for assessing the effectiveness of audit in the operational branch of a commercial bank. The effective work of the auditor is aimed at eliminating the risk of branch activity as well as maximizing the profit generated by this branch.

Originality/value - The value of the article is original proposal of procedure for a multicriterial assessment of the effectiveness of the work of an internal auditor examining the operations of a commercial bank operating branch.
\end{abstract}

Keywords: internal audit, bank, efficiency, risk

\section{Cytowanie}

Oleksyk, P. (2017). Ocena efektywności pracy audytora wewnętrznego w oddziale operacyjnym banku komercyjnego. Finanse, Rynki Finansowe, Ubezpieczenia, 3 (87/1), s. 89-96. DOI: 10.18276/frfu.2017.87/1-08. 